\title{
Pemberian Bimbingan Belajar Bahasa Inggris kepada Anak Usia Dini di Panti Asuhan Bani Adam 'As Medan
}

\author{
Hairani Siregar*1, Gaby Octavia² \\ 1,2Jurusan Kesejahteraan Sosial, Fakultas Ilmu Sosial dan Ilmu Politik, Universitas Sumatera Utara, \\ Indonesia \\ *e-mail: $\underline{\text { hairani fisipusu@yahoo.co.id }}{ }^{1}{ }_{\text {gabyoctva@gmail.com }}^{2}$
}

\begin{abstract}
Abstrak
Kemampuan menguasai Bahasa Inggris sangat penting di era modern ini karena bahasa Inggris tidak hanya digunakan di bidang akademik, tetapi juga di dunia kerja. Namun, masih banyak masyarakat Indonesia yang memiliki kemampuan bahasa Inggris yang rendah terutama mereka yang berasal dari kelompok kurang mampu seperti anak yatim. Di sisi lain, muncul berbagai lembaga kursus Bahasa Inggris yang memasang tarif begitu fantastis. Diperlukan alternatif pemecahan masalah yaitu adanya kegiatan pembelajaran Bahasa Inggris gratis. Anak di Panti Asuhan Bani Adam 'As pun merasakan hal yang sama. Banyak dari mereka yang berminat belajar Bahasa Inggris namun kondisi tidak memungkinkan bagi mereka untuk melakukannya. Oleh sebab itu, kegiatan praktikum ini merupakan hal yang sangat tepat sasaran untuk dilakukan. Program Intervensi yang digunakan dalam kegiatan Praktikum ini adalah Intervensi Komunitas oleh Zastrow yang terdiri dari; Intake, Assesmen dan Perencanaan Intervensi, Penyeleksian Anggota, Pengembangan Kelompok, Evaluasi dan Terminasi. Sebagai tambahan, terjadi peningkatan keterampilan membaca dan berbicara serta motivasi mereka dalam belajar bahasa Inggris. Selain itu, program ini juga memberikan manfaat bagi kedua belah pihak yang terlibat (yatim dan siswa) secara sosial dan pendidikan. Artinya terdapat dampak positif yang signifikan setelah pelaksanaan program ini.
\end{abstract}

Kata kunci: Anak Yatim Piatu, Kemampuan Bahasa Inggris, Mahasiswa

\section{Abstract}

The ability to master English is highly essential in the modern era because English is not only used in academic field, but also in the workplace. However, many Indonesian people still have low English skills especially those who come from disadvantaged group like orphans. On the other hand, there are various English course institutions that put up rates so fantastic. An alternative to problem solving is the existence of free English learning activities. Children in The Bani Adam 'As Orphanage feel the same way. Many of them are interested in learning English but conditions do not allow for them to do so. Therefore, this practicum activity is a very targeted thing to do. The Intervention Program used in this Practicum activity is a Community Intervention by Zastrow consisting of; Intake, Assessment and Intervention Planning, Member Selection, Group Development, Evaluation and Termination. In addition, there was an increase in their reading and speaking skills as well as their motivation in learning English. Moreover, this program also benefitted both parties inveolved (orphans and students) socially and educationally. This means that there was a significant positive impact after the implementation of this program.

Keywords: English Skills, Orphans, University students

\section{PENDAHULUAN}

Kemampuan bahasa adalah yang sering diasosiasikan sebagai kemampuan intelektual seseorang. Bahasa merupakan salah satu hal yang sangat dibutuhkan dalam menumbuhkan kemampuan professional seseorang (Lestari, 2019). Salah satu yang dapat dilihat dalam language skills (kemampuan berbahasa) seseorang adalah dengan menguasai bahasa asing. Salah satu bahasa asing yang paling penting di dunia adalah Bahasa Inggris. Bahasa ini merupakan lingua franca, yaitu bahasa yang memiliki penutur terbanyak. Diharapkan jika seseorang memiliki kemampuan berbahasa Inggris, maka peluang di masa depan untuk bersaing mendapatkan hidup yang lebih baik akan meningkat (Tamrin \& Yanti, 2019).

Bahasa Inggris menjadi bahasa asing yang dapat dikatakan sebagai bahasa asing yang wajib dikuasai oleh siswa, namun bahasa Inggris adalah salah satu mata pelajaran yang diaggap 
sukar oleh sebagian besar siswa pada hampir semua jenjang pendidikan. Namun tidak bisa dipungkiri, bahwa bahasa Inggris merupakan bahasa global yang dipakai di seluruh dunia. Apabila siswa mahir berbahasa Inggris, diharapkan para siswa dapat menghadapi kompetisi yang semakin ketat di era globalisasi.

Fokus utama Panti Asuhan Bani Adam 'As adalah membantu, menyantuni, membina serta memberikan fasilitas anak-anak dalam sebuah komunitas (asrama). Di tempat ini juga mereka dibina, diajari dan dididik bagaimana hidup normal seperti teman-teman mereka yang lain tentang pentingnya kasih sayang, akhlak dan ilmu pengetahuan. Dengan latar belakang pendidikan pesantren, para pengasuh tidak kesulitan ketika berhadapan dengan pembinaan akhlak. Hanya saja mereka mendapat kesulitan saat membimbing anak-anak belajar, terutama belajar Bahasa Inggris.

Berdasarkan hasil interview dengan anak panti disana, penulis mendapatkan informasi bahwa anak panti disana sangat berminat untuk mengikuti bimbingan belajar Bahasa Inggris, namun kondisi mereka kurang memungkinkan untuk mengikuti lembaga kursus Bahasa Inggris diluar sana. Menyadari hal ini, maka penulis berusaha mengakomodir dan merencanakan sebuah bimbingan belajar Bahasa Inggris dimana pada pelaksanaannya akan disesuaikan dengan level pendidikan anak panti di Panti Asuhan Bani Adam 'As.

\section{METODE}

Dalam kegiatan pelaksanaan pemecahan masalah, metode yang digunakan yaitu metode GroupWork menurut Zastrow, yaitu: intake, assesmen dan intervensi, penyeleksian, pengembangan kelompok, evaluasi dan terminasi.

a. Intake: diawali dengan adanya pengakuan mengenai masalah yang mungkin dapat dipecahkan melalui pendekatan kelompok. Dalam tahap ini dilakukan perumuskan persetujuan dan komitmen antara pekerja sosial dengan klien untuk melakukan kegiatankegiatan melalui kelompok.

b. Assesmen dan Perencanaan Intervensi: pada tahap ini, Gaby bersama anggota kelompok mengidentifikasi permasalahan, tujuan yang ingin dicapai serta merencanakan tindakantindakan pemecahan masalah dalam kelompok tersebut. Tools Assesment yang digunakan adalah FGD (Focus Group Discussion) guna mengumpulkan kelompok dan membahas topik yang telah ditentukan. Dan pada tahap ini diperlukan Teori kognitif yaitu teori yang mengatakan bahwa belajar merupakan suatu proses perubahan presepsi dan pemahaman yang dapat diukur dan diamati. Model ini lebih berorientasi pada studi bagaimana siswa belajar berpikir. Fokus studiya adalah pada pertanyaan perkembangan kognitif. Bagi guru yang terpenting adalah bagaimana dapat mempengaruhi perkembangan berpikir dan bagaimana guru dapat menyesuaikan pengajaran dengan tingkat perkembangan kognitif para siswa.

c. Tahap Penyeleksian Anggota: dalam tahap penyeleksian anggota, Gaby menyeleksi anggota berdasarkan usia. Hal ini dilakukan untuk mengkelompokkan anak-anak panti agar dapat menerima pembelajaran sesuai dengan usia.

d. Tahap Pengembangan Kelompok: pada tahap ini Gaby memainkan peranan yang aktif dalam mendorong kelompok guna mencapai tujuan yang telah disepakati. Pada tahap ini, memberikan materi pentingnya belajar bahasa Inggris dan tips-tips belajar bahasa Inggris yang menyenangkan bagi mereka. Setelah itu juga mengajarkan mereka tentang kosakata bahasa Inggris dengan menggunakan media interaktif berupa scrabble.

e. Tahap Evaluasi dan Terminasi: kegiatan ini dievaluasi berdasarkan ketercapaian tujuan kegiatan. Kegiatan yang meliputi penyampaian materi, diskusi kelas, diskusi kelompok dan kuis. Dari hasil observasi, selama kegiatan berlangsung, peserta antusias dan semakin termotivasi untuk belajar bahasa Inggris. Kemudian pada tahap terminasi, dimana tujuan yang direncanakan sudah tercapai sehingga dapat menyelesaikan kontrak. 


\section{HASIL DAN PEMBAHASAN}

\subsection{Survei Pendahuluan dan Persiapan Materi Kegiatan}

Survei Pendahuluan ini pada awalnya dilaksanakan pada tanggal 4-September-2021 di Panti Asuhan Bani Adam 'As Medan yang beralamat di Pasar 2 Jl. Mangaan III Ps. II No. 216 MABAR, Kecamatan Medan Deli, Kota Medan, Sumatera Utara. Kegiatan ini bertujuan untuk menanyakan ketersediaan pengelola Panti Asuhan terhadap kegiatan pengabdian masyarakat. Setelah itu, diperoleh kesepakatan bahwa akan diadakannya kegiatan pengabdian masyarakat kurang lebih selama 3 bulan, dimulai dari bulan September 2021 sampai awal bulan Desember 2021.

\subsection{Sosialisasi dan Kegiatan Bimbingan Belajar}

Kegiatan sosialisasi dan bimbingan belajar Bahasa Inggris yang dilakukan di Panti Asuhan Bani Adam 'As dilakukan selama seminggu tiga kali terhitung dari tanggal 10 September 2021. Pelatihan kegiatan mengenai Bahasa Inggris dihadiri oleh 10-15 orang anak panti asuhan tersebut.

Kegiatan awalnya bermula dari sosialisasi mengenai pentingnya mengetahui Bahasa Inggris, dan menjelaskan alasan-alasan yang menarik untuk belajar Bahasa Inggris yang bertujuan untuk menarik antusias anak panti mengenai Bahasa Inggris. Kemudian, kegiatan yang dilaksanakan selama masa praktikum ini adalah bermain dan belajar, hal ini untuk menghindari anak-anak panti merasa jenuh dan bosan dengan proses pembelajaran yang dilakukan.

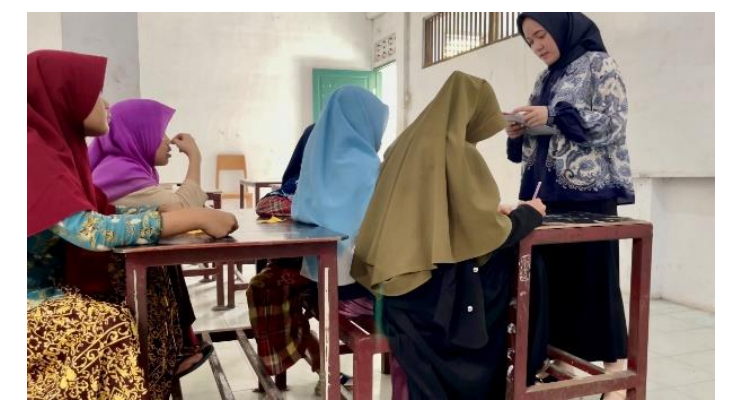

Gambar 1. Proses Pembelajaran Bahasa Inggris

Kegiatan ini dievaluasi berdasarkan ketercapaian tujuan kegiatan, yang mana kegiatan ini bertujuan untuk mengetahui capaian keberhasilan peserta dalam memahami materi yang diberikan, dan juga untuk melihat kesesuaian materi dengan kemampuan peserta kegiatan. Evaluasi dilaksanakan dengan tujuan untuk melihat tingkat keberhasilan peserta memahami materi yang disampaikan dalam pelaksanaan kegiatan pelatihan, selain itu juga untuk memantau kesesuaian materi dengan kebutuhan peserta pelatihan, dan keefektifan proses kegiatan. Hasil dari kegiatan yang dilakukan adalah terjadi peningkatan keterampilan membaca dan berbicara serta motivasi mereka dalam belajar bahasa Inggris. Artinya terdapat dampak positif yang signifikan setelah pelaksanaan program ini.

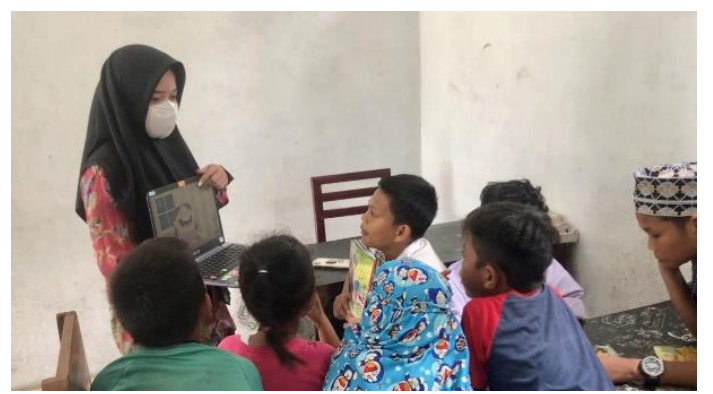

Gambar 2. Proses Mengajar Melalui Media Video Pembelajaran 
Dari penjelasan diatas berdasarkan evaluasi, didapatkan hasil: (1) Peserta pelatihan sangat antusias mengikuti semua rangkaian kegiatan pelatihan, mereka memahami materi ajar yang disampaikan, terlihat dengan hasil latihan dan praktik yang menunjukkan adanya peningkatan pemahaman dan keterampilan serta penguasaan materi, (2) bertambahnya minat mereka dalam mempelajari Bahasa Inggris yang terlihat dari keaktifan mereka dalam melakukan praktik, mengadakan diskusi tanya jawab, serta kehadiran jumlah peserta yang tidak berkurang, yaitu sebanyak 10 orang.Suasana yang terbentuk dari kegiatan pemberian materi pelatihan ini lebih nonformal, yaitu sangat santai disesuaikan dengan tempat dan anak yang dihadapi, (4) peserta pelatihan merasa terbantu dengan adanya kegiatan tambahan praktik percakapan Bahasa Inggris ini, mengingat mereka tidak ada yang mendapatkan pembelajaran tambahan di luar sekolah, sehingga mereka merasa senang mengikuti kegiatan dengan suasana berbahasa Inggris.

Pengumpulan data yang dipakai dalam kegiatan ini adalah: (1) soal tes unjuk kerja, digunakan untuk mengukur jumlah penguasaan kosakata peserta. Tes dikerjakan peserta secara individual yang diberikan di akhir materi pembelajaran, dan (2) catatan lapangan, dilakukan dengan mendokumentasikan proses pembelajaran bahasa Inggris dan foto kegiatan selama proses belajar mengajar baik sebelum maupun ketika dilaksanakan tindakan.

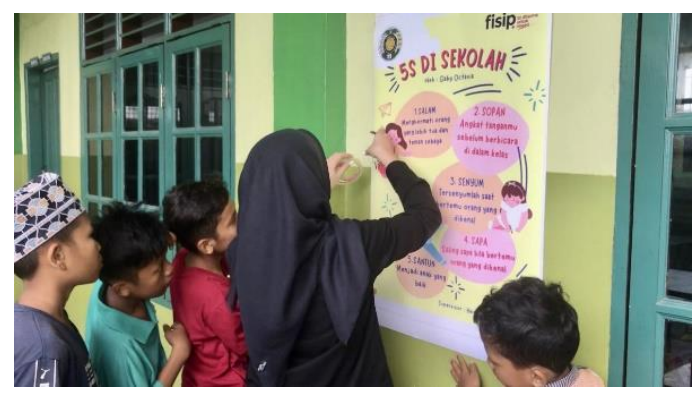

Gambar 3. Penempelan Poster

Tidak hanya memberikan sosialisasi dan kegiatan tentang Bahasa Inggris, penulis juga memberikan praktik mencuci tangan yang benar serta membagikan masker. Setelah itu, mendesign dan menempelkan poster bertemakan etika dan sopan santun juga turut mengiisi agenda pada kegiatan ini.

\section{KESIMPULAN}

Kegiatan ini meliputi penyampaian materi, diskusi kelas, diskusi kelompok dan kuis. Dari hasil observasi, selama kegiatan pendampingan berlangsung, peserta antusias dan semakin termotivasi untuk belajar bahasa Inggris. Dengan kegiatan ini diharapkan kemampuan peserta dalam belajar bahasa Inggris semakin meningkat sehingga bisa mereka manfaatkan dimasa yang akan datang.

Berdasarkan kegiatan yang telah dilaksanakan, maka dapat ditarik kesimpulan bahwa terdapat perubahan sikap dari yang kurang aktif, tidak antusias dan kurang terlibat menjadi lebih aktif. Selain itu, terjadi peningkatan keterampilan membaca dan berbicara dalam bahasa Inggris. Selama pendampingan berlangsung, juga tampak adanya proses interaktif aktif antara pemateri dan peserta. Oleh karena itu, sangat disarankan untuk melakukan program yang sama.

\section{UCAPAN TERIMA KASIH}

Ucapan terima kasih disampaikan kepada Pengelola Panti Asuhan Bani Adam As, Bapak Bona yang telah banyak membantu penulis dalam kegiatan ini, serta menerima penulis layaknya seperti saudara sendiri. Serta anak-anak yang berada di Panti Asuhan Bani Adam 'As yang menyambut dengan ramah dan hangat sehingga kegiatan yang dilakukan dapat berjalan baik dan lancar. Semoga kita semua selalu dalam lindungan Tuhan Yang Maha Esa. 


\section{DAFTAR PUSTAKA}

Fakhrudin, Mohammad. (2017). Penerapan Kaidah Berbahasa dalam Percakapan Berbahasa Indonesia. Journal of Language Learning and Research (JOLLAR) Volume 1 (1) 41-57. DOI: 10.22236/JOLLAR_1(1)41-57.

Lestari, S. D. (2019). Pendampingan Pembelajaran Bahasa Inggris Dasar Pada Eks-TKI Di Dusun Sumberwaru Desa Tamanagung Kecamatan Cluring Kabupaten Banyuwangi. JATI EMAS (Jurnal Aplikasi Teknik Dan Pengabdian Masyarakat), 3(1), 38. https://doi.org/10.36339/je.v3i1.188

Tamrin, A. F., \& Yanti, Y. (2019). Peningkatan keterampilan bahasa Inggris masyarakat pegunungan di Desa Betao Kabupaten Sidrap. Transformasi: Jurnal Pengabdian Masyarakat, 15(2), 61-72. https://doi.org/10.20414/transformasi.v15i2.1673 


\section{Halaman Ini Dikosongkan}

